\title{
PENGARUH PENGGUNAAN MEDIA WAYANG KERTAS ANIMASI HEWAN TERHADAP KEMAMPUAN MENULIS TEKS FABEL SISWA KELAS VII MTS HUSNUL KHOTIMAH KAMPEK
}

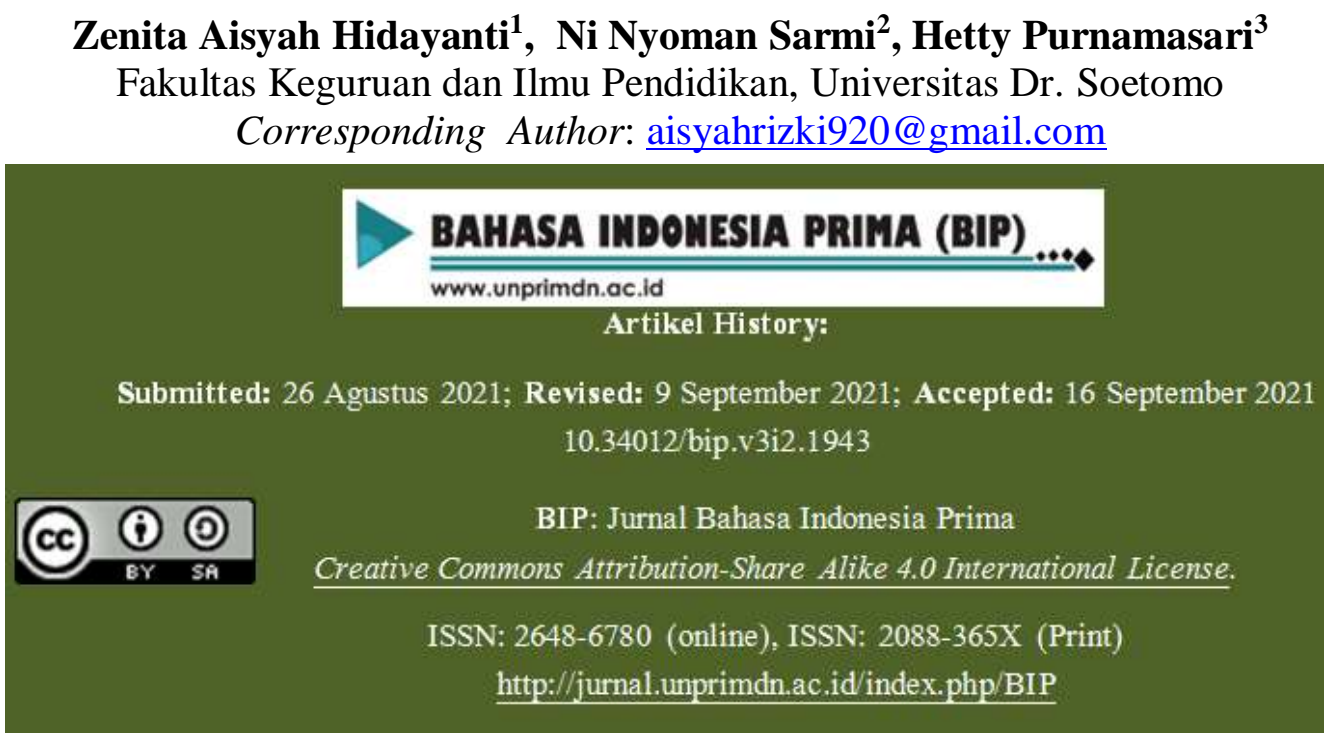

Abstrak-Media wayang kertas hewan sendiri adalah media hasil dari modifikasi wayang kulit yang bahannya diganti dengan kertas karena disesuaikan dengan bentuk hewan fabel yang nantinya akan mudah dibentuknya. Tujuannya untuk mengetahui pengaruh media wayang kertas hewan terhadap kemampuan menulis teks fabel. Jenis penelitian yang digunakan kuantitatif, menggunakan desain penelitian true experimental design dengan metode pretest posttest control group design. Teknik pengumpulan data menggunakan metode tes dan observasi. Pengujian uji prasyarat yakni uji normalitas dan homogenitas dengan resiko kesalahan 5\%. Hasil uji-t menggunakan sampel berkolerasi maka diperoleh hasil uji-t posttest kelas kontrol dan eksperimen adalah $\mathrm{t}$ hitung $=20,92$ nilai $\mathrm{t}$ tabel $=2,06$. Menurut kriteria pengujian $\mathrm{t}$ jika $\mathrm{t}$ hitung > tabel, maka Ho ditolak, sehingga terdapat perbedaan kemampuan akhir antara peserta didik kelas kontrol dengan peserta didik kelas eksperimen. Jadi, dapat disimpulkan bahwa media wayang kertas hewan berpengaruh pada kemampuan menulis teks dabel siswa kelas VII MTs Husnul Khotimah Kampek Burneh.

Kata kunci: wayang kertas hewan, menulis, teks fabel

\begin{abstract}
The animal paper puppet media itself is the media resulting from the modification of the leather puppet whose material is replaced with paper because it is adapted to the shape of the fable animal which will later be easily formed. The aim is to determine the effect of animal paper puppet media on the ability to write fable texts. The type of research used is quantitative, using a true experimental design with a pretest posttest control group design method. Data collection techniques using test and observation methods. Prerequisite tests are tests for normality and homogeneity with a 5\% risk of error. The results of the t-test using a correlated sample, the results of the posttest t-test for the control and experimental classes are $\mathrm{t}$-test $=20.92$, $\mathrm{t}$-table value $=2.06$. According to the $\mathrm{t}$ test criteria, if $\mathrm{t}$ count $>$ table, then Ho
\end{abstract}


is rejected, so there is a difference in the final ability between control class students and experimental class students. So, it can be concluded that the paper animal puppet media has an effect on the ability to write dabel texts for class VII students of MTs Husnul Khotimah Kampek Burneh.

Keywords: animal paper puppet, writing, fable text

\section{A. Pendahuluan}

Pendidikan merupakan suatu hal yang sangat penting bagi setiap individu, hal ini yang membuat kita ingin meningkatkan pengetahuan yang belum didapat sebelumnya. Pendidikan sendiri telah menjadi keharusan bagi setiap orang untuk menyalurkan bakat serta mengeksplor kemampuan yang telah dimiliki setiap individu baik dalam akademik maupun dalam non akademik. Salah satu hal yang tidak dapat dipisahkan dengan pendidikan yakni adanya sebuah pembelajaran. Pembelajaran sendiri yakni proses interaksi dari peserta didik dan sumber belajar pada suatu lingkungan belajar yang diajarkan oleh guru terhadap siswa yang berupa penyampaian informasi yang dapat bermanfaat bagi satu sama lainnya.

Pembelajaran yang baik akan diperoleh dari pengajar yang baik dan siswa yang mau belajar dengan baik. Pengajar yang baik yakni pengajar yang dapat menciptakan keefektifan dalam pembelajaran pada saat ini sangat diperlukan dalam bidang pendidikan yang semakin cangkih pada setiap tahunnya, ini sangat diperlukan dalam bidang pendidikan karena jika pengajar mampu menciptakan kegiatan belajar mengajar secara efektif akan menimbulkan dampak yang positif terhadap siswa, dalam hal tersebut bisa membawa siswa mampu menangkap materi dan dapat memahaminya dengan mudah. Pengajar memiliki peran penting dalam dunia pendidikan, salah satunya yakni sebagai fasilitator dalam mentransfer ilmu pengetahuan yang dimilikinya terhadap siswa ataupun orang yang memerlukannya. Pengajar dalam dunia pendidikan tidak akan lepas dari menghadapi siswa dalam setiap mengajar, karena siswa merupakan salah satu objek dalam pendidikan karena siswa sendiri merupakan sebagai penerima pengetahuan yang akan disampaikan oleh pengajar.

Dalam dunia pembelajaran saat ini yang telah menggunakan kurikulum 2013, siswa diharapkan mampu belajar lebih aktif dan lebih disiplin dalam mengatur waktu yang dimilikinya. Selain kedua harapan tersebut terhadap siswa guru juga harus mampu menciptakan pengajaran yang efektif karena jika pengajar menggunakan metode pembelajaran, strategi pembelajaran, media pembelajaran yang tidak tepat maka akan mempengaruhi situasi pembelajaran yang akan dilaksanakan dalam kelas, pengajar juga diharapkan membuat inovasi-inovasi terbaru dalam proses kegiatan belajar mengajar agar proses belajar mengajar tidak monoton yakni salah satunya dengan penggunakan media dalam menyampaikan iformasi dalam proses pembelajaran agar di dalam kelas situasinya lebih berbeda dan lebih baru serta menyenangkan dalam penerimaan informasi pembelajaran.

Secara terminologis fabel berasal dari bahasa latin fabula. Cerita fabel merupakan cerita tentang kehidupan binatang yang berperilaku menyerupai manusia. Fabel termasuk jenis cerita fiksi, bukan kisah tentang kehidupan nyata. Knapp dan Watkins (dalam Rahmawati, 
2016:1323) Fabel adalah salah satu bentuk teks narasi yang mengisahkan tentang kehidupan binatang yang berperilaku menyerupai manusia. Cerita fabel sering juga disebut cerita moral karena pesan yang ada didalam cerita fabel berkaitan erat dengan moral. Oleh karena itu, bagian dari cerita fabel berisi pernyataan yang menunjukkan amanat dari penulis kepada pembaca. Berbeda halnya dengan cerpen atau novel yang penyampaian amanatnya dilakukan secara tersurat, dalam fabel pembaca langsung bisa menemukan amanat atau nilai moral pada bagian akhir atau kesimpulan cerita. Secara umum, teks fabel memiliki struktur yang terdiri atas orientasi, komplikasi, resolusi, dan koda. Ciri yang paling menonjol dalam teks fabel adalah adanya pesan moral yang disampaikan melalui tokoh-tokoh binatang dalam teks fabel.

Percayakah kamu bahwa belajar itu tidak hanya pada manusia? Kita dapat pada apa yang ada dibumi, misalnya belajar pada alam, tumbuhan, atau binatang. Keseluruhan kehidupan jenis tumbuhan-tumbuhan suatu habitat disebut flora, sedangkan keseluruhan kehidupan jenis binatang disebut fauna. Pada pelajaran ini kamu akan diajak memahami dan mencermati teks cerita fabel. Tokoh pada cerita fabel biasanya binatang. Teks cerita fabel tidak hanya mengisahkan kehidupan binatang, tetapi juga mengisahkan kehidupan manusia dengan segala karakternya.

Binatang-binatang yang ada pada cerita fabel memiliki karakter seperti manusia. Karakter mereka ada yang baik dan ada juga yang tidak baik. Mereka mempunyai sifat jujur, sopan, pintar dan senang bersahabat, serta melakukan perbuatan terpuji. Mereka ada yang berkarakter licik, culas, sombong, suka menipu, dan ingin menang sendiri. Cerita fabel tidak hanya ditujukan kepada anak-anak, tetapi juga kepada orang dewasa. Setelah membaca dan memahami teks cerita fabel, kita dapat belajar pada karakter-karakter binatang tersebut. Cerita fabel menjadi salah satu sarana potensial dalam menanamkan nilai-nilai moral. Kamu dapat belajar dan mencontoh karakter-karakter yang baik dari binatang itu agar kita memiliki sifat terpuji.

Media pembelajaran sendiri yakni sebuah alat untuk membantu guru dalam menyampaikan materi yang akan diajarkan kepada siswanya yang nantinya materi tersebut akan disampaikan bisa diterima serta dipahami dengan mudah oleh siswa. Media dalam proses pembelajaran sangat diperlukan dimana fungsi media itu sendiri sangat penting sebagai penunjang proses pembelajaran. Sedangkan pengertian yang lebih luas media pembelajaran adalah sebuah alat yang mempunyai fungsi menyampaikan pesan pelajaran dengan lebih mudah dipahami. Media pembelajaran merupakan bentuk saluran yang digunakan oleh guru untuk menyalurkan pesan, informasi atau bahan pelajaran kepada penerima pesan yakni siswa. (Sadiman, 2014:6) Media berasal dari bahasa latin dan merupakan bentuk jamak dari kata medium yang secara harfiah berarti perantara atau pengantar, Media adalah perantara atau pengantar pesan dari pengirim kepada penerima pesan. Maka dari itulah penggunaan media pembelajaran perlu ditingkatkan di semua sekolah termasuk sekolah-sekolah yang berada di pelosok desa.

Penerapan media pembelajaran pada setiap sekolah tidaklah mudah karena setiap sekolah memiliki karakteristik berbeda-beda, guru harus meneliti terlebih 
dahulu bagaimana karakteristik serta keadaan sekolah tersebut cocoknya menerapkan media apa yang bisa diterapkan setelah itu guru membuatterlebih dahulu medianya sebelum proses pembelajaran, selain itu guru harus membuat perkiraan apakah media yang telah dibuat tersebut bisa digunakan sesuai apa tidak dengan materi yang akan disampaikan serta dengan lingkungan setiap sekolahnya. Seiring denganberjalannya waktu kini pengajar dapat membuat media pembelajaran yang praktis, karena teknologi yang semakin canggih dapat dimanfaatkan untuk membuat media pembelajaran multimedia ini hanya dengan layar maka media itu bisa jadi, semakin modern zaman maka semakin modern juga inovasi-inovasi media pembelajaran yang ada dan yang akan tercipta.

Penggunaan media pembelajaran sangat diperlukan oleh guru dan siswa maka sebab itu penggunaan media pembelajaran diperlukan sebuah pemilihan media yang cocok dengan materi yang akan disampaikan. Media pembelajaran yang akan digunakan juga harus sesuai dengan tingkat pemahaman siswa, kemampuan siswa, dan jumlah siswa di MTs Husnul Khotimah Kampek, Burneh ini memiliki jumlah siswa yang terbilang besar. Siswa yang sedemikian banyaknya akan sulit memahaminya jika setiap pengajar menggunakan model pembelajaran yang kurang efektif, untuk itulah diperlukan sebuah media pembelajaran pada saat menyampaikan materi agar siswa menjadi lebih paham saat menerima materi yang akan disampaikan oleh guru.

Pengembangan media di sekolah MTs Husnul Khotimah Kampek, Burneh ini masih sangat minim guru yang menggunakan media dalam menyampaikan materi dalam pembelajaran maka media sangat diperlukan sekali oleh guru karena kebanyakan dari guru pada saat mengajar banyak melakukan pengajaran dengan metode ceramah pada saat memberikan materi terhadap siswanya, respon dari siswa yang diajarkanpun tidak terlalu baik dalam meresponnya karena pada setiap pengajarannya monoton dan membosankan untuk hal tersebut maka media sangat dibutuhkan dalam pengajaran ini agar bisa membuka kreatifitas mereka yang masih terpendam.

Dalam hal ini Dananjaya (dalam Yundiafi 2003:2) menyatakan bahwa foklor mengungkapkan kepada kita secara sadar atau tidak sadar bagaimana masyarakat pendukungnya berpikir, selain itu foklor juga mengabdikan apa-apa yang dirasakan penting oleh masyarakat pendukungnya. Hal itu juga dapat dibuktikan dari banyaknya cerita binatang yang berasal dari berbagai daerah yang diangkat menjadi cerita anak. Pada penulisan teks fabel harus memperhatiakan struktur dari teks fabel tersebut, supaya teks fabel yang akan ditulis menjadi suatu cerita yang menunjukkan bahwa teks tersebut adalah teks fabel. Maka dari itu penguasaan struktur teks fabel menjadi pokok permasalahan, karena banyak siswa-siswi tidak mengetahui atau memahami struktur teks fabel. Kurangnya referensi dan penguasaan terhadap struktur teks fabel menjadikan siswasiswi tidak mampu menulis teks fabel dengan baik. Selain penguasaan struktur yang harus diperhatikan, didalam teks fabel juga tidak kalah pentingnya memperhatikan unsur /ciri kebahasaan teks fabel tersebut. Karena penguasaan ciri kebahasaan teks fabel dapat menetukan 
teks tersebut mempunyai ciri kebahasaan teks yang berbeda dengan teks lainnya. Penguasaan ciri kebahasaan akan sempurna ketika siswa-siswi mampu menulis teks fabel dengan penggunaan strutur teks fabel dan ciri kebahasaan yang terdapat dalam teks fabel.

Kemampuan menulis teks fabel adalah kesanggupan memahami dan menuangkan ide dalam bentuk tertulis cerita binatang dengan melihat struktur dan juga ciri kebahasaan teks fabel. Menulis berarti mengorganisasikan gagasan secara sistematik serta mengungkapkannya secara tersurat. Sehubungan dengan hal ini Morsey (dalam Tarigan, 1984:4) mengatakan, " menulis dipergunakan oleh orang terpelajar untuk mencatat / merekam, meyakinkan, melaporkan / memberitahukan, dan mempengaruhi dan maksud serta tujuan seperti itu hanya hanya dapat dicapai dengan baik oleh orang-orang yang dapat menyusun pikiran dan mengutarakannya dengan jelas, kejelasan ini tergantung pada pikiran, organisasi, pemakaian kata-kata, dan struktur kalimat." Pengaruh penguasaan struktur dan ciri kebahasaan teks fabel pada umumnya mempunyai pengaruh yang sangat signifikan. Akan tetapi dalam penelitian ini akan terlihat jelas bahwa penguasaan manakah yang lebih dominan dalam kemampuan menulis teks fabel.

Bisa jadi penguasaan struktur teks berpengaruh dengan kemampuan menulis teks fabel, atau malah sebaliknya penguasaan ciri kebahasaan yang berpengaruh dengan kemampuan menulis teks fabel. Kemampuan menulis teks fabel berpengaruh dari struktur dan ciri kebahasaannya, seperti yang terlihat dalam buku pelajaran Bahasa Indonesia Kelas VII SMP/MTs yang mengharuskan siswa untuk menulis teks berdasarkan struktur yang sudah dikuasai akan menjadikan teks tersebut sempurna dan menjadi satu kesatuan teks yang baik. Namun, kenyataanya para siswa terlihat kurang mampu menulis teks fabel berdasarkan penguasaan struktur dan ciri kebahasaan teks fabel. Penguasaan para siswa mengenai struktur dan ciri kebahasaan masih sangat rendah. Kurang mampunya siswa dalam menulis teks fabel diduga disebabkan oleh berbagai faktor, yakni salah satunya adalah tidak dapat menguasai struktur dan ciri kebahasaan teks fabel sehingga siswa kesulitan dalam menulis teks fabel secara sempurna yang sesuai dengan struktur dan ciri kebahasaan teks fabel.

Mata pelajaran Bahasa Indonesia ini menjadi salah satu mata pelajaran yang mudah dipahami akan tetapi jika penyampaian materinya tidak tepat, maka materi yang akan disampaikan tersebut tidak akan bisa diterima. Materi-materi dalam pelajaran Bahasa Indonesia sendiri banyak yang bisa membuat siswa lebih kreatif dengan menyalurkan imajinasinya yang sebelumnya tidak dapat disalurkan. Pada materi teks prosedur jika tidak diimbangi dengan penggunakan media pada saat menyampaikannya maka tidak akan sampai tujuan yang akan disampaikannya, bila hanya mengandalkan dengan ceramah saja maka pembelajaran itu akan terlihat sangat membosankan, berbeda jika materi yang akan disampaikan dengan sebuh media atau alat pembelajaran sebagai perantaranya maka siswa nantinya akan lebih mudah memahami materi yang tersampaikan dengan media, karena pusat perhatian siswa tidak hanya pada materinya saja yang disampaikan dengan ceramah akan tetapi perhatian bisa tergantikan dengan adanya media, jika medianya bisa menarik 
perhatian siswa maka akan lebih mudah membuat materi yang akan disampaikan akan lebih gampang penyampaiannya dan diserap dengan mudah dengan tujuan yang akan disampaikan dalam pembelajarannya tersebut tercangkup dengan adanya penyampaian media tersebut.

Media pembelajaran sebagai alat peraga dalam kegiatan belajar mengajar mengandung maksud serta tujuan yang baik untuk menyampaikan pesan atau informasi sehingga dapat menarik perhatian dan minat siswa dalam belajar. Untuk meningkatkan semangat siswa dalam proses belajar maka di MTs Husnul Khotimah Kampek, Burneh ini perlu adanya peningkatan pada media pembelajaran dalam mata pelajaran Bahasa Indonesia khususnya dalam hal menulis teks fabel. Penggunaan media visual dalam materi menulis teks fabel ini diharapkan dapat meningkatkan keterampilan siswa dalam hal kepenulisan. Menulis merupakan kegiatan yang bisa dikatakan sangat membosankan akan tetapi jika pembelajarannya dilakukan dengan media pembelajaran maka akan terasa lebih mudah dan menyenangkan.

Media pembelajaran yang digunakan di MTs Husnul Khotimah Kampek, Burneh dalam mata pelajaran Bahasa Indonesia ialah media pembelajaran wayang kertas hewan. Media wayang kertas hewan sangat diperlukan oleh guru. Media wayang kertas hewan ini merupakan media yang menyajikan gambar-gambar hewan yang dibuat menjadi wayang untuk mempermudah atau meningkatkan keterampilan imajinasi siswa dalam menulis teks fabel yang disampaikan melalui penggunaan wayang kertas hewan pada siswa di MTs Husnul Khotimah Kampek, Burneh. Dalam menulis serta memahami teks fabel diperlukan stimulus agar siswa dapat lebih aktif menulis serta mengingat-ngikat tahap demi tahap history yang ada, hal ini bisa disajikan dengan memainkan media wayang kertas hewan.

Media pembelajaran wayang kertas hewan ini memiliki manfaat yang baik dalam pembelajaran, salah satunya dalam hal menulis teks fabel yang di sajikan dalam bentuk wayang kertas hewan. Oleh karena itu di MTs Husnul Khotimah ini media pembelajaran yang digunakan diharapkan dapat meningkatkan keterampilan menulis teks fabel dengan kreasi imajinasi dari siswa dalam membuatnya. Berhubungan dengan media wayang kertas hewan yang digunakan, maka sangat diharapkan media tersebut dapat membuat siswa lebih aktif dalam kegiatan belajar dalam kelas seta bisa aktif bertanya, dengan adanya gambar-gambar hewan yang lucu yang disajikan dalam bentuk wayang yang dapat mempermudah siswa dalam memahami materi teks fabel dengan lebih baik lagi dan dapat mengaplikasinya dengan menulis teks fabel dengan baik dan benar sesuai dengan aturan yang telah disampaikan dalam materi yang telah guru sampaikan serta dapat mempermudah siswa dalam proses imajinasi.

Menurut peneliti di MTs Husnul Khotimah perlu adanya peningkatan dalam penggunaan media saat pembelajaran. Terutama dalam penelitian ini mengangkat tentang media pembelajaran wayang kertas hewan untuk meningkatkan keterampilan menulis teks fabel. Telah dijelaskan sebelumnya bahwa menulis teks fabel perlu adanya media pembelajaran supaya minat siswa untuk menulis lebih semangat dan mengerti alur ceritanya mulai dari tahap pertama, kedua, ketiga dan seterusnya. Menurut peneliti keterampilan menulis teks febel akan tumbuh pada diri 
siswa jika ada dorongan yang kuat, seperti halnya teori behaviorisme yaitu adanya stimulus dan respon, menurut saya di sini media pembelajaran dapat dijadikan sebagai stimulus untuk merangsang siswa agar pembelajaran keterampilan menulis bisa meningkat dan siswa tidak bosan untuk mengikat tahap demi tahap ceritanya.

Media yang diangkat dalam penelitian ini memang tujuan utamanya adalah untuk pembelajaran materi Bahasa Indonesia, yaitu dalam materi menulis teks fabel yang ditampilkan dalam bentuk wayang kertas hewan. Menulis teks fabel membutuhkan waktu yang tidaklah sedikit itu artinya dalam menulis teks fabel dibutuhkan waktu yang lumayan lama untuk berimajinasi serta mengingat-ingat tahap demi tahap alur ceritanya. Adanya media pembelajaran pada mata pelajaran Bahasa Indonesia diharapkan juga dapat memotivasi para pendidik lain dalam mata pelajaran yang berbeda agar dapat membuat siswa lebih nyaman dalam menerima materi.

Media pembelajaran wayng kertas hewan yang baik dapat menunjang keterampilan menulis yang baik pula. Keterampilan menulis siswa MTs Husnul Khotimah Kampek Burneh memang sudah terlihat bagus, mereka sudah banyak yang sudah membuat karya-karya dari kepenulisan entah itu puisi ataupun cerpen yang telah tercetak pada majalah sekolah yang setiap tahunnya di cetak. Akan tetapi alangkah lebih baik lagi jika media pembelajaran visual ini diterapkan untuk meningkatkan keterampilan menulis teks fabel yang melibatkan langkah demi langkah alur ceritanya. Karena menulis teks fabel tidak seperti menulis puisi yang hanya butuh beberapa kata, akan tetapi menulis teks fabel membutuhkan penalaran yang sungguh-sungguh dalam setiap menuliskan langkah demi langkah kejadian alur ceritanya yang telah terjadi.

Penelitian ini menggunakan metode deskripsi, dimana peneliti akan berusaha mendeskripsikan data-data yang telah diperoleh dari proses penelitian di MTs Husnul Khotimah. Dalam penelitian ini tidak lupa juga terdapat dokumentasi ketika pembelajaran berlangsung agar dapat diketahui secara kongkret proses pembelajaran menggunakan media pembelajaran visual bisa berhasil di terapkan apa tidak.

Penelitian ini bertujuan untuk meningkatkan motivasi siswa dalam menerima dan menerapkan materi yang telah di dapatkan yang nanti ke depannya semoga bisa dijadikan sebagai referensi dalam pembelajaran. Harapan dari penulis sangat banyak terutama bagi siswa semoga siswa dapat meningkatkan kegiatan belajarnya dengan semangat karena telah adanya stimulus yang berupa media pembelajaran yang diberikan oleh guru

\section{B. Metode Penelitian}

Penelitian yang dilakukan peneliti adalah penelitian kuantitatif. Desain penelitian ini adalah penelitian eksperimen yaitu true experimental design disebut sebagai true experimental design karena peneliti dapat mengontrol semua variable luar yang mempengaruhi jalannya eksperimen. true experimental design dibagi menjadi dua jenis yaitu posttest only control dan pretest-prosttest control design, adapun dari kedua jenis tersebut yang digunakan dalam penelitian ini yaitu pretest-posttest control design. Pada desain ini peneliti akan membandingkan nilai dari dua kelompok yaitu kelompok eksperimen yang diberikan tindakan yaitu dengan media wayang kertas hewan dan kelompok 
control yang tidak mendapat tindakan yaitu media wayang kertas hewan.

Dalam mengambil sampel kelas eksperimen dan kelas kontrol, peneliti menggunakan teknik simple rondom sampling. Disebut simple (sederhana) menurut Sugiyono (2015:82) karena pengambilan anggota sampel dari populasi dilakukan secara acak tanpa memperhatikan stara yang ada dalam kelas populasi.

Cara pengambilan sampel teknik simple rondom sampling biasanya dilakukan dengan cara undian, lotre, memilih bilangan dari daftar bilangan secara acak, dan lain-lain (Sugiyono, 2015:63), adapun cara pengambilan sampel penelitian ini nantinya dengan cara undian, maka dua kelas yang keluar dari kotak undian akan diambil sebagai sampel dalam penelitian ini. Dari hasil tersebut diperoleh kelas A dan B. Dengan kelas A sebagai kelas kontrol yang tidak diberi perlakuan atau tidak menggunakan media terhadap materi menulis teks fabel dan kelas B sebagai kelas eksperimen yang diberi perlakuan dengan menggunakan media wayang kertas hewan terhadap kemampuan menulis teks fabel. Peneliti menggunakan kelas kontrol dikarenakan perbandingan kelas A dan kelas B tingkat keaktifan lebih terlihat kelas A dari pada kelas B maka dari itu untuk meningkatkan kemampuan menulis teks fabel, peneliti memilih kelas B untuk dijadikan kelas eksperimen agar bisa menambah kemampuan peserta didik untuk menulis teks fabel. Instrumen penelitian yang digunakan dalam penelitian ini adalah portofolio, lembar observasi, angket respon siswa, serta perangkat pembelajaran, berupa RPP yang dilengkapi dengan LKS beserta petunjuk pengisian.
Teknik pengumpulan data merupakan suatu cara yang dilakukan untuk memperoleh data pada suatu penelitian. Berdasarkan kisi-kisi instrumen penelitian yang telah ditentukan, pengumpulan data pada penelitian ini menggunakan metode tes, dan observasi. Analisis data yang digunakan dalam penelitian ini yaitu uji coba instrumen dan uji prasyarat. Uji instrumen meliputi uji validitas dan uji reabilitas, sedangkan uji prasyarat meliputi uji normalitas, uji homogenitas, uji-t, uji gain. Data yang akan diuji menggunakan uji prasyarat adalah data pretest dan posttest yang diperoleh dari kelas eksperimen dan kontrol, kemudian dapat diketahui terdapat pengaruh atau tidak dalam penelitian tersebut.

\section{Hasil dan Pembahasan}

KKK Pada bagian ini akan dibahas mengenai hasil analisis untuk menjawab rumusan masalah, yaitu 1) Bagaimana kemampuan menulis teks fabel siswa kelas VII MTs Husnul Khotimah Kampek,Burneh sebelum penggunaan media wayang kertas hewan 2) Bagaimana pelaksanaan pembelajaran menulis teks fabel siswa kelas VII MTs Husnul Khotimah dengan tanpa menggunakan media dan menggunakan media wayang kertas hewan. Data ini diperoleh dari hasil penelitian eksperimen menggunakan desain true eksperimental yang dilaksanakan pada siswa kelas VII B MTs Husnul Khotimah sebagai kelas eksperimen yang akan diterapkan media wayang kertas hewan dalam pembelajaran teks fabel. Data berupa hasil belajar siswa yang diperoleh dari hasil pretest dan posttest kelas VII A MTs Husnul Khotimah sebagai kelas Kontrol. Data yang telah diperoleh peneliti dari hasil penelitian di kelas VII MTs Husnul Khotimah, selanjutnya akan dianalisis secara statistik inferensial dengan tujuan untuk mnemukan jawaban dari permasalahan. 
Data yang telah diambil dari kedua kelas penelitian kemudian diuji dengan uji normalitas dan uji homogenitas, untuk mnegetahui apakah data tersebut berdistribusi normal dan homogen atau tidaknya. Pada perhitungan uji normalitas menggunakan uji Lilliefors, data dikatakan normal dengan kriteria $\mathrm{L}_{\max } \leq \mathrm{L}_{\text {tabel }}$ (Sundayana, 2016:63). Pada perhitungan uji homogenitas menggunakan Alpha Cronbach dengan kaidah keputusan $\mathrm{F}_{\text {hitung }}$ $\leq \mathrm{F}_{\text {tabel }}$ maka $\mathrm{HO}$ diterima.

Peneliti menghitung data pada kelas eksperimen tahap pritest dan posttest dengan uji normalitas dan hasil ujinya sebagai berikut :

Ho : Data berdistribusi normal

Ha : Data tidak berdistribusi normal

Berdasarkan tabel di atas dapat dilihat bahwa hasil uji normalitas pretest kelas eksperimen diperoleh $\mathrm{d}_{\text {hitung }}=0,167<$ $\mathrm{d}_{\text {tabel }}=0,254$, maka data dinyatakan berdistribusi normal. Sedangkan pada hasil normalitas pretest kelas kontrol diperoleh $\mathrm{d}_{\text {hitung }}=0,188<\mathrm{d}_{\text {tabel }}=0,254$, maka data dinyatakan berdistribusi normal. Jadi dapat disimpulkan bahwa data pritest dan posttest kelas kontrol dan kelas eksperimenberdistribusi normal.

Setelah menghitung normalitas pada kelas eksperimen selanjutnya pada kelas eksperimen. Berikut hasil dari uji normalitas kelas eksperimen:

Tabel 2. Hasil Uji Normalitas

\begin{tabular}{|c|c|c|c|c|c|}
\hline \multicolumn{3}{|c|}{ Prited } & \multicolumn{3}{c|}{ Postrst } \\
\hline Dhitung & Deablel & Ket & Dhitung & Dobbel & Ket \\
\hline 0,157 & 0.254 & Nornal & 0,214 & 0,254 & Nontral \\
\hline
\end{tabular}

Ho : Data berdistribusi normal

Ha : Data tidak berdistribusi normal

Berdasarkan tabel di atas dapat dilihat bahwa hasil uji normalitas pretest kelas eksperimen diperoleh $\mathrm{d}_{\text {hitung }}=0,167<$ $\mathrm{d}_{\text {tabel }}=0,254$, maka data dinyatakan berdistribusi normal. Sedangkan pada hasil normalitas posttest kelas eksperimen diperoleh $\mathrm{d}_{\text {hitung }}=0,214<\mathrm{d}_{\text {tabel }}=0,254$, maka data dinyatakan berdistribusi normal. Jadi dapat disimpulkan bahwa data pritest dan posttest kelas kontrol dan kelas eksperimenberdistribusi normal.

Setelah dilakukan uji normalitas dan telah diketahui bahwa data berdistribusi normal, maka selanjutnya menghitung uji homogenitas. Uji homogenitas dilakukan untuk melihat objek yang diteliti apakah memiliki varian yang sama atau tidak. Metode yang digunakan dalam uji homogenitas ini adalah metode yang membandingkan antara varian terbesar dengan varian yang terkecil. Nilai yang digunakan dalam pengujian homogenitas ini merupakan nilai pretest kelas eksperimen dan kontrol.

Tabel 3. Hasil Uji Homogenitas

\begin{tabular}{|c|c|c|c|c|}
\hline No & Data & $F_{\min }$ & $F_{\text {tete }}$ & Kcputnsan \\
\hline 1 & $\begin{array}{l}\text { Homogenitas prets kelas } \\
\text { cksperimen dan kontrol }\end{array}$ & 0,60 & 1,98 & Homogen \\
\hline 2 & $\begin{array}{l}\text { Homogenitas postest } \\
\text { kelas cksperimen dan } \\
\text { kontrol }\end{array}$ & 0,49 & 1.98 & Homogen \\
\hline
\end{tabular}

Berdasarkan tabel 3 dapat diketahui $\mathrm{F}_{\text {tabel }}$ homogenitas pretest kelas eksperimen dan kontrol 1,98 dengan taraf signifikan 0,05 . $F_{\text {hitung }}<\mathrm{F}_{\text {tabel }}=0,60<1,98$, menurut kriteria pengujian homogenits pretest kelas eksperimen dan kelas kontrol dinyatakan bahwa Ho diterima, karena $F_{\text {hitung }}<\mathrm{F}_{\text {tabel }}$ maka kedua varian homogen $\left(\mathrm{v}_{1}=\mathrm{v}_{2}\right)$.

Kedua, $\mathrm{F}_{\text {tabel }}$ homogenitas postest kelas eksperimen dan kelas kontrol diperoleh 1,98 dengan resiko kelasan 0,05 . F Fitung homogenitas postest kelas eksperimen dan kelas kontrol, sehingga $F_{\text {hitung }}<F_{\text {tabel }}=0,49$ $<$ 1,98. Menurut kriteria pengujian homogenitas postest kelas eksperimen dan kelas kontrol dinyatakan bahwa Ho diterima, karena $F_{\text {hitung }}<\mathrm{F}_{\text {tabel }}$ maka kedua varian homogen $\left(\mathrm{v}_{1}=\mathrm{v}_{2}\right)$.

Jadi, dapat disimpulkan kedua data yakni, pretest kelas eksperimen dan kelas kontrol, maupun postest kelas eksperimen dan kelas kontrol dinyatakan Ho diterima, yakni memiliki varian yang homogen karena Fhitung < Ftabel. Selain itu gambar 4.24 dapat diketahui perbedaan hasil homogenitas pretest kelas eksperimen dan kelas kontrol dengan hasil homogenitas 
BIP: Jurnal Bahasa Indonesia Prima Vol. 3, No. 2, 2021, September 2021, PP.

pretest kelas eksperimen dan kontrol semakin meningkat dan berpengaruh.

Setelah diketahui berdistribusi normal dan homogen, selanjutnya dilakukan uji-t untuk mengetahui adakah pengaruh media papan memori kesenian tari tradisional Madura terhadap kemampuan menulis siswa kelas VII MTs Husnul Khotimah. Berikut hipotesis pada uji ini :

Tabel 4. Hasil Uji-t

\begin{tabular}{|c|c|c|c|c|}
\hline Data & $\begin{array}{c}\text { Taraf } \\
\text { Sinifilan }\end{array}$ & thtad & $t_{i 2 k}$ & Keterangas \\
\hline $\begin{array}{l}\text { Nila pretest dam poitlest } \\
\text { Gela esiperimen }\end{array}$ & 0.05 & 2,180 & 2,0484 & $\begin{array}{l}\text { Ho ditolak dan } \\
\text { Ha diterima }\end{array}$ \\
\hline
\end{tabular}

Berdasarkan tabel 4 diperoleh $\mathrm{t}_{\text {hitung }}=$ 2,180 dan $t_{\text {tabel }}=2,0484$ dari uji-t post-test eksperimen jadi dapat disimpulkan bahwa $t_{\text {hitung }}>t_{\text {tabel }}$ hasil dari uji-t eksperimen lebih besar sehingga Ho ditolak dan $\mathrm{Ha}$ diterima. Jadi,dapat disimpulkan bahwa terdapat pengaruh yang signifikan pada penelitian terhadap pengaruh media wayang kertas hewan terhadap kemampuan menulis teks fabel siswa kelas VII MTs Husnul Khotimah.

Uji yang dapat menguatkan uji-t adalah uji gain, yang digunakan untuk mengetahui gambaran umum peningkatan kemampuan menulis teks fabel antara sebelum dan sesudah diberi perlakukan (beruppa media wayang kertas hewan) antara pretest dan posttest pada kelas Eksperimen dan kelas Kontrol dalam penelitian. Besarnya peningkatan sebelum dan sesudah pembelajaran dihitung menggunakan rumus gain ternormalisasi. Berikut hasil pengujian gain ternormalisasi

Tabel 5. Uji Gain Ternomalisasi

\begin{tabular}{|c|c|c|c|c|c|}
\hline Siswa & $\mathrm{X}$ & $\mathrm{Y}$ & $\mathrm{Y}-\mathrm{X}$ & $\begin{array}{c}\text { Gji } \\
\text { Gain }\end{array}$ & Kriteria \\
\hline 1 & 70 & 80 & 10 & 0,33 & Sedang \\
\hline 2 & 60 & 80 & 20 & 0,50 & Sedang \\
\hline 3 & 65 & 80 & 15 & 0,43 & Sedang \\
\hline 4 & 55 & 70 & 15 & 0,33 & Sedang \\
\hline 5 & 65 & 80 & 15 & 0,43 & Sedang \\
\hline 6 & 75 & 80 & 5 & 0,20 & Rendah \\
\hline 7 & 60 & 70 & 10 & 0,25 & Rendah \\
\hline 8 & 50 & 80 & 30 & 0,60 & Sedang \\
\hline 9 & 55 & 80 & 25 & 0,56 & Sedang \\
\hline
\end{tabular}

\begin{tabular}{|c|c|c|c|c|c|}
\hline 10 & 50 & 65 & 15 & 0,30 & Rendah \\
\hline 11 & 65 & 80 & 15 & 0,43 & Sedang \\
\hline 12 & 65 & 80 & 15 & 0,43 & Sedang \\
\hline 13 & 50 & 80 & 30 & 0,60 & Sedang \\
\hline 14 & 60 & 80 & 20 & 0,50 & Sedang \\
\hline 15 & 65 & 80 & 15 & 0,43 & Sedang \\
\hline 16 & 65 & 80 & 15 & 0,43 & Sedang \\
\hline 17 & 75 & 80 & 5 & 0,20 & Rendah \\
\hline 18 & 70 & 75 & 5 & 0,17 & Rendah \\
\hline 19 & 65 & 75 & 10 & 0,29 & Rendah \\
\hline 20 & 75 & 75 & 0 & 0,00 & Tetap \\
\hline 21 & 70 & 80 & 10 & 0,33 & Sedang \\
\hline 22 & 75 & 75 & 0 & 0,00 & Tetap \\
\hline 23 & 70 & 75 & 5 & 0,17 & Penurunan \\
\hline 24 & 55 & 80 & 25 & 0,56 & Sedang \\
\hline 25 & 50 & 75 & 25 & 0,50 & Sedang \\
\hline 26 & 75 & 75 & 0 & 0,00 & Tetap \\
\hline 27 & 75 & 80 & 5 & 0,20 & Rendah \\
\hline 28 & 75 & 80 & 5 & 0,20 & Rendah \\
\hline Iumla & 1805 & $\begin{array}{c}217 \\
0 \\
\end{array}$ & 365 & $\begin{array}{c}9,3515 \\
87 \\
\end{array}$ & \\
\hline
\end{tabular}

Berdasarkan tabel di atas, diatas dapat disimpulkan bahwa terdapat siswa yang mendapatkan kategori tinggi, sedang dan rendah, Dapat dilihat pada tabel diatas, hasil belajar siswa yang memiliki kategori peningkatan tinggi sebanyak 19 anak dan nilai sedang 15 sebanyak, dan kategori nilai rendah 4 orang .

\section{Simpulan}

Berdasarkan hasil penelitian pengaruh penggunaan media wayang kertas hewan terhadap kemampuan menulis teks fabel siswa kelas VII MTs Husnul Khotimah, Kampek tahun ajaran 2019-2020, untuk menjawab rumusan masalah yang ada pada penelitian maka akan dijabarkan simpulan sebagai berikut:

1. Kemampuan menulis teks fabel siswa kelas kontrol dengan tanpa menggunakan media wayang kertas hewan pada saat mengerjakan tugas teks fabel terdapat 19 siswa yang tidak tuntas dan hanya 9 siswa yang tuntas dari 28 siswa dalam satu kelas. Berdasarkan hal tersebut dapat disimpulkan bahwa kemampuan 
menulis siswa dapat dikategorikan rendah dengan tanpa diterapkannya media wayang kertas hewan dalam menulis materi teks fabel. Siswa dalam menulis teks fabel masih belum bisa memilih kata-kata yang benar dalam menceritakan cerita fabel dan masih belum bisa menyalurkan imajinasinya dalam proses menulis cerita fabel.

2. Proses pelaksanaan pembelajaran menulis teks fabel siswa kelas VII MTs Husnul Khotimah sebelum digunakannya media wayang kertas hewan siswa mengalami rasa bosan dalam menerima materi yang dijelaskan oleh guru serta memiliki sedikit masalah disaat proses menuliskan cerita fabel, siswa masih banyak yang belum bisa mengekspor ide-ide dalam menuliskan cerita fabel dan masih banyak yang tidak tuntas. Maka dengan demikian peneliti menerapkan media wayang kertas hewan terhadap menulis teks fabel agar siswa dalam menerima materi lebih bersemangat mendengarkan serta dalam proses menulis cerita fabel siswa lebih bisa mengekspor imajinasi yang lebih baik lagi dalam membuat teks fabel, dari diterapkannya media wayang kertas hewan siswa mulai banyak yang tuntas dalam menuliskan teks fabel.

3. Kemampuan menulis teks fabel siswa kelas eksperimen dengan menggunakan media wayang kertas hewan pada saat mengerjakan tugas teks fabel untuk memudahkannya menulis teks fabel terdapat 15 siswa yang tuntas dan 13 siswa yang tidak tuntas dari 28 siswa dalam satu kelas. Bedasarkan hal tersebut dapat disimpulkan bahwa kemampuan menulis siswa dapat dikategorikan sedang dengan diterapkannya media wayang kertas hewan dalam menulis materi teks fabel. Dalam mengerjakan tugas siswa lebih banyak benar pada soal nomor 1 menentukan tema apa yang sesuai dengan gambar yang diberi oleh guru dan soal nomor 2 menentukan judul apa yang sesuai dengan gambar wayang kertas hewan yang diberi oleh guru. Pada pemilihan kata dan kesesuaian urutan dalam kepenulisan cerita teks fabel, siswa sudah mulai bagus dalam pekerjaannya.

4. Pengaruh dalam penggunaan media wayang kertas hewan akan dilakukan dengan uji hipotesis yang digunakan untuk mengukur adanya pengaruh penggunaan media wayang kertas hewan terhadap kemampuan menulis teks fabel siswa kelas VII MTs Husnul Khotimah, Kampek, dengan taraf signifikan 0,05 kelas eksperimen dan kelas kontrol terdapat pengaruh karena hasil uji-t posttest kelas kontrol dan eksperimen adalah $t_{\text {hitung }}$ $=20,921>$ nilai $t_{\text {tabel }}=2,06$ sehingga Ho ditolak dan Ha diterima, maka terdapat perbedaan kemampuan akhir peserta didik kelas kontrol dengan kelas eksperimen.

\section{Daftar Pustaka}

Arifin, Zainal. 2011. Evaluasi Pembelajaran. Bandung: PT. Remaja. Rosda karya.

Darsono. M. 2000. Belajar dan Pembelajaran. Semarang: Unnes Press.

Djaali. 2007. Psikologi Pendidikan. Jakarta: Bumi Aksara.

Hasanuddin dan M. Abdullah. 2014. Buku Guru Bahasa Indonesia. Jakarta: Kementerian Pendidikan dan Kebudayaan.

Hasanuddin dan M. Abdullah. 2014. Buku Siswa Bahasa Indonesia. Jakarta: Kementerian Pendidikan dan Kebudayaan. 
Jabrohim, dkk. 2001. Cara Menulis Kreatif. Yogyakarta: Pustaka Pelajar.

Mulyono, Sri. 1982. Wayang dan Filsafat Nusantara. Jakarta: CV Haji.

Masagung. Munadi, Y. 2013. Media Pembelajaran: Sebuah Pendekatan Baru. Jakarta: Gp Press Group.

Nanda. 2010. Ensiklopedi Wayang. Yogyakarta: Absolut.

Oktavianti, Rizki \& Agus Wiyanto. 2014. Pengembangan Media Gayanghetum (Gambar Wayang Hewan Dan Tumbuhan) dalam Pembelajaran Tematik Terintegrasi Kelas IV SD. Mimbar Sekolah Dasar 1 (1). 65-70.

Purwanto. 2009. Evaluasi Hasil Belajar. Yogyakarta: Pustaka Pelajar.

Sadiman, A., dkk. 1990. Media Pendidikan: Pengertian Pengembangan, dan Pemanfaatannya. Jakarta: CV Rajawali.

Silabus Mata Pelajaran Bahasa dan Sastra Indonesia (Peminatan Ilmu Bahasa Dan Budaya).

Siswanto, W. 2014. Cara Menulis Cerita. Malang: Aditya Media Publishing.

Sugiyono. 2010. Metode Penelitian Kuantitatif, Kualitatif dan $R \& D$. Bandung: Alfabeta Rosda Karya.

Wahono, Sawali dan Drs. Mafrukhi. 2013. Mahir Berbahasa Indonesia. Jakarta: Erlangga. 